This is an author produced version of a paper published in Small ruminant research. This paper has been peer-reviewed but does not include the final publisher proof-corrections or journal pagination.

Citation for the published paper:

Kumm, Karl-Ivar. (2009) Profitable Swedish lamb production by economies of scale. Small ruminant research.

Volume: 81 Issue: 1, pp. 63-69.

http://dx.doi.org/10.1016/j.smallrumres.2008.11.006

Access to the published version may require journal subscription. Published with permission from: Elsevier.

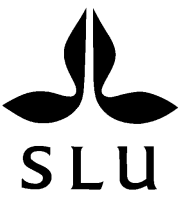

Epsilon Open Archive http://epsilon.slu.se 


\title{
Profitable Swedish lamb production by economies of scale
}

\author{
Karl-Ivar Kumm \\ Department of Animal Environment and Health, Swedish University of Agricultural \\ Sciences \\ P.O. Box 234, SE-532 23 Skara, Sweden \\ Telephone $+46(0) 51167256$ \\ Fax +46(0)51167204 \\ Karl-Ivar.Kumm@hmh.slu.se
}

\begin{abstract}
Economic sustainability assumes profitability (revenues $\geq$ costs including annual cash expenses as well as family labor and investments). Calculations suggest that sheep flocks of more than 500 ewes can be profitable under Swedish conditions whereas smaller flocks are unprofitable unless they are managed by cheap existing resources including buildings, fences, machinery and family labor with low or no opportunity costs. Despite this economies of scale less than $1 \%$ of the Swedish sheep flocks have 500 or more ewes. Possible reasons are, according to interviews with lamb producers which have built up for Swedish conditions large sheep flocks of 90-900 ewes (average 380), growth sacrifices when developing large flocks and lack of accessible cheap land for providing large flocks with pasture and winter forage. The growth sacrifices reducing revenues or increasing costs during or immediately after the growth period include low production of primiparous ewes, reclamation of additional land and capital costs of new buildings before the flock has been expanded to the intended number. The chas-flow is another problem for expanding sheep operations.
\end{abstract}

Profitable lamb production presupposes large areas of land with zero or low opportunity costs. In fertile flatlands the opportunity costs are too high and in forest dominated regions it is difficult to get hold of large enough areas near the farm centre for pasture and winter feed production. The latter problem can be solved by leasing cheap land further away and transporting feed and grazing animals, and by extending present pastures by incorporating adjacent overgrown pastures, marginal arable land and forest land. Another requirement for long-term profitable lamb production is to reduce the costs of new sheep sheds below what is a common cost level in Sweden.

Keywords: Sheep; Lamb production; Economies of scale; Profitability; Growth sacrifices

\section{Introduction}

Historically, sheep have been an important part of Swedish subsistence farming. In 1927 Sweden had 143,000 holdings with sheep and the average flock size was only three ewes (Jordbruksverket, 2005). Since the mid 20th century sheep have increasingly become a tool for keeping the landscape open on marginal part time or "hobby" farms where dairy or other animal production have ceased. In 2006 Sweden had barely 8,000 holdings with sheep and the average flock size was 29 ewes. Less than $6 \%$ of the Swedish sheep were in holdings with more than 400 ewes (Table 1). This small-scale structure is in contrast to large 
sheep-producing countries in Europe such as United Kingdom and Spain there the average flock sizes are larger than 200 ewes (Eurostat, 2008). In New Zealand, the largest lamb exporter to EU including Sweden (Jordbruksverket, 2006), the average flock size of farms in the Sheep and Beef Farm Survey is nearly 3,000 stock units of sheep (Meat \& Wool New Zealand, 2008; one stock unit $=$ one $55 \mathrm{~kg}$ ewe rearing a single lamb). Not only Swedish but generally North European lamb production will have severe difficulties to compete with import from e.g. New Zealand on a more deregulated world market if the cost of production is not decreased considerably (Dýrmundsson, 2006). The EU policy reform (CAP) with decoupling of subsidies from production makes cost reductions still more important.

Table 1. The size structure of the Swedish lamb production in 2007.

\begin{tabular}{|l|r|r|r|r|}
\hline Size of holding & $\begin{array}{r}\text { Number of } \\
\text { holdings }\end{array}$ & $\begin{array}{r}\text { \% of all } \\
\text { holdings }\end{array}$ & $\begin{array}{r}\text { Number of } \\
\text { ewes }\end{array}$ & \% of all ewes \\
\hline $1-49$ ewes & 6,787 & 85.4 & 100,491 & 43.5 \\
\hline $50-99$ ewes & 729 & 9.2 & 48,956 & 21.2 \\
\hline $100-399$ ewes & 409 & 5.1 & 68,343 & 29.6 \\
\hline$\geq 400$ ewes & 26 & 0.3 & 13,041 & 5.6 \\
\hline$\Sigma$ ewes & 7,951 & 100.0 & 230,831 & 100.0 \\
\hline
\end{tabular}

Source: Statistiska centralbyrån, 2008.

Not only small-scale structure resulting in e.g. high labor demand per ewe but also short grazing season are severe competition disadvantages in Swedish, and North European, lamb production. Swedish sheep are fed indoors half the year. Small flocks and expensive buildings due to cold, snowy winters, and strict animal welfare regulations (Djurskyddsmyndigheten, 2004), can result in total labor and building costs of more than 1,000 SEK per ewe and year (Sveriges lantbruksuniversitet, 2008; $1 \mathrm{SEK}=0.14 \mathrm{USD}$, average 2007-2007).

Most of the present Swedish holdings are too small for covering the costs of new production resources including buildings and manpower provided at market prices (Sveriges lantbruksuniversitet, 2008). Instead they use cheap existing resources, e.g. buildings, fences and machinery, which otherwise would remain unused after other kinds of production on previous full time farms have ceased. The small sheep holders get most of their income from other occupations and thus have low requirement for income from their sheep.

Sweden produces only $37 \%$ of its lamb and mutton consumption (Jordbruksverket, 2006). The Swedish slaughter industry aims to increase the lamb production. To some extent operations using existing cheap resources can increase the lamb production. However, the main increase must come from new and expanding operations and these must probably be able to cover the costs of new means of production provided at market prices. Without ability to cover market prices of labor, new buildings and machinery the production will hardly be economically sustainable. The industry wants to slaughter more lambs during winter, spring and early summer (Sjödin, 2007). This desire is illustrated by the price of lamb being around 40 SEK per kg carcass weight during these times of the year but only 30 SEK or less during late summer and autumn at the end of the grazing season when the traditional Swedish sheep operations supplies most of their lambs. 
Economies of scale seem to be necessary to make Swedish lamb production profitable. However, lack of experience of large scale lamb production and small farms with small and scattered fields and pastures are severe obstacles for developing economies of scale. The average holding size in forest dominated areas in Sweden is only 23 ha of arable land and 5 ha of semi-natural pastures (Jordbruksverket, 2007). In flatlands the holdings are larger and the farm layout better, but there the opportunity cost of land is probably too high for profitable lamb production at least on fertile land if current (2007/08) high grain prices last.

In forest dominated regions farmers aiming to manage large flocks would need to access pastures and fields far away from the farm centre. This results in long transport of feed from the fields to where the sheep are wintered and long trips for the supervision of animals during the grazing period. The Swedish animal welfare policy prescribes that the animals normally are inspected by the owner/keeper at least once a day (Djurskyddsmyndigheten, 2004).

The aim of this paper is to investigate the possibility of making Swedish lamb production profitable by economies of scale and to find ways to overcome obstacles for building up large, profitable flocks. The obstacles are of two kinds: growth sacrifices (reduced revenues or increased costs during or immediately after the growth period) and lasting diseconomies of scale (e.g. longer average distance from the farm centre to the fields and pastures, and thus higher transportation costs). The growth sacrifices vanish when the growth has been carried through whereas the diseconomies of scale come about when the scale has been increased.

\section{Material and methods}

\subsection{Calculations}

Economies of scale was estimated for lamb production by calculating the profitability (=revenues less total costs in 2006 prices) for sheep holdings of different sizes with slaughter of lambs in the late winter, spring and early summer. Multiple lambing times from December to April with slaughter of early born lambs before the birth of late born ones were assumed in order to reduce the building space requirement. The profitability was calculated in the interval of 100-800 ewes in the case of new resources provided at market prices. Data are not available for larger flocks than 800 ewes in Sweden. In the case of cheap existing resources the calculations are restricted to an interval of 50-200 ewes. It is generally not realistic to manage flocks larger than 200 ewes on cheap existing resources in the intense Swedish lamb production with indoor feeding half the year and strict animal welfare regulations.

The main revenues are the sale of slaughter lambs and environmental payments for the care of semi-natural pastures and grass leys. The breed of ewes used was crosses between Swedish fine-wool and Dorset served by Texel rams. Average production per ewe is 2.0 weaned lambs per year with a carcass weight of $19.5 \mathrm{~kg}$ sold at approximately 40 SEK per kg in late winter, spring and early summer (Sveriges lantbruksuniversitet, 2008). The environmental payments vary in the interval of 300-3,000 SEK per ha depending on the level of nature values and location in Sweden. There is also a single farm payment of 
1,100 SEK per ha of semi-natural pasture, which assumes grazing, included in the revenues. In the calculations, the model farm is supposed to be situated in an area in Central Sweden with average grazing season and average grass yield for Sweden. It is also supposed that $60 \%$ of the grazing area is semi-natural pastures with only basic natural values and that $40 \%$ is temporary pasture, which is a typical distribution in Central Sweden. The environmental payment is in this case 300 SEK per ha of ley and 2200 SEK per ha of semi-natural pastures including the single farm payment.

A larger part of semi-natural pastures, semi-natural pastures with especially high natural values, and/or production in less favored areas would result in higher environmental payment and/or income support. However, also cost of production increases due to e.g. higher cost of pasture and silage production and/or decreased revenues from lamb sales due to poorer grazing. The incremental revenues and the incremental costs cancel each other out in many cases (Kumm, 2006). It is beyond the scope of this paper to further analyze this question.

The main costs are feed, buildings, labor and ewe replacement costs. Other costs include minerals, animal health, machinery for feeding and mucking out, and interest on funds invested in the sheep operation (Sveriges lantbruksuniversitet, 2008). The consumption of pasture, silage and concentrate is estimated by the Swedish feed-norm for ruminants (Spörndly, 2003). Pasture and silage is produced on the farm whereas concentrate (feed grain and protein feed, e.g. soya bean meal) is bought in. Yields and costs of seed and plant nutrients in roughage production are based on data from the Swedish University of Agricultural Sciences (Sveriges lantbruksuniversitet, 2006). Machinery and labor costs in roughage production are based on agricultural contractor rates in the case of new means of production provided at market prices. In the case of cheap existing resources they are based on farmers own out-dated machinery with no opportunity cost but high labor demand (Kumm, 2006). In the basic calculation the opportunity cost of land is zero, which was the reality before the drastic price-increase of grain in 2007 (Swedish University of Agricultural Sciences, 2006). In a sensitivity analysis the opportunity cost of arable land is 1,000 SEK per ha, which is the forecast opportunity cost for 2008 in Central Sweden (Sveriges lantbruksuniversitet, 2008).

Labor demand per ewe for different flock sizes in the case of new resources is as follows: 100 ewes 5 h, 200 ewes 4 h, 400 ewes 3 h, 800 ewes 2.5 h (Sjödin, 2007). In the case of cheap existing resources, including old buildings that originally were built for other purposes than lamb production, the labor demand is supposed to be $50 \%$ higher for each flock size. The building space per ewe, including lambs, is $2.8 \mathrm{~m}^{2}$ and the costs of new buildings for different flock sizes are estimated by a cost calculation program by the Swedish Board of Agriculture (Kumm, 2006) in the basic costing. In a sensitivity analysis the costs of new buildings are reduced by $50 \%$, which correspond to the real cost in some cases when farmers themselves have built simple, but well functioning, houses (Kumm, 2006). The cost of labor and interest rate are 170 SEK per hour and $5 \%$ for new resources provided at market price, and 100 SEK and $2 \%$ for cheap existing resources.

\subsection{Interviews}

Ways to overcome the obstacles of building up large, profitable flocks were researched by telephone interviews with 20 lamb producers who have built up for Swedish 
conditions large sheep flocks of 90-900 ewes (average 380). They were systematically selected as successfully expanding lamb producers by persons within the Swedish slaughter and sheep industry.

The interviewees were asked about which growth sacrifices they had experienced during the expansion phase, what they had done to reduce these sacrifices and what they would do differently if they were to repeat the expansion of the flock again with the experience they had gained. They were also asked about lasting diseconomies of scale of their sheep operations and what they had done to overcome them. Finally, they were asked about obstacles for further future expansion of their own sheep flocks.

\section{Results}

\subsection{Calculations}

Table 2 suggests that the lamb production is profitable (revenues $>$ costs) in the basic calculation only if cheap existing recourses can be used and the flock is larger than 100 ewes. In the case of new resources provided at market prices the production is unprofitable even in the largest flock size of 800 ewes. One important reason is the high costs of new buildings. In flocks with 100-200 ewes the economic loss is very high if new buildings and labor at normal market wage are considered in the costings.

The costs of not only buildings but also costs of labor, silage and concentrate are very high per ewe compared to corresponding costs in e.g. New Zealand (Meat \& Wool New Zealand, 2008). The main reasons are indoor feeding half the year of the ewes, small flocks, and rearing of lambs entirely or mainly indoors for slaughter when the prices are highest in late winter, spring or early summer. Other reasons for the high Swedish costs compared to New Zealand are high yield per ewe (2.0 respectively 1.2 lambs) and strict animal welfare regulations.

In flocks with 800 ewes full cost coverage is nearly reached thanks to lower labor demand and lower building cost per ewe than in the smaller flocks. Also "other costs" are somewhat lower than in smaller flocks mainly thanks to lower costs per ewe for machinery for winter feeding. Cost of silage is the same independent of flock size in the case of new resources provided at market prices because of the assumption that contractors do the entire field works. If these tasks are done by own machinery the cost in the largest operation may be the same as the cost of contractors but considerably higher in smaller operations due to high capital costs of new machinery per hectare and thus per ewe. 
Table 2. Calculated revenues, costs and profitability in Swedish lamb production with slaughter in late winter, spring and early summer. SEK per ewe in 2006 prices.

\begin{tabular}{|c|c|c|c|c|c|c|c|}
\hline \multirow{2}{*}{ Number of ewes } & \multicolumn{3}{|c|}{ Cheap existing resources } & \multicolumn{4}{|c|}{ New resources \& market prices } \\
\hline & 50 & 100 & 200 & 100 & 200 & 400 & 800 \\
\hline Revenues & & & & & & & \\
\hline Lamb sales & 1548 & 1552 & 1560 & 1552 & 1560 & 1560 & 1560 \\
\hline Cull ewe & 30 & 30 & 30 & 30 & 30 & 30 & 30 \\
\hline Wool & 15 & 15 & 15 & 15 & 15 & 15 & 15 \\
\hline Environmental payment & 208 & 208 & 208 & 208 & 208 & 208 & 208 \\
\hline$\Sigma$ revenues & 1801 & 1805 & 1813 & 1805 & 1813 & 1813 & 1813 \\
\hline Costs & & & & & & & \\
\hline Ewe replacements & 120 & 120 & 120 & 120 & 120 & 120 & 120 \\
\hline Silage & 146 & 146 & 146 & 192 & 192 & 192 & 192 \\
\hline Pasture & 47 & 47 & 47 & 117 & 117 & 117 & 117 \\
\hline Concentrate & 386 & 386 & 386 & 386 & 386 & 348 & 348 \\
\hline Labor & 996 & 728 & 575 & 825 & 652 & 525 & 380 \\
\hline Building \& bedding & 68 & 68 & 68 & 646 & 511 & 443 & 409 \\
\hline Other costs & 400 & 296 & 243 & 392 & 325 & 289 & 269 \\
\hline$\Sigma$ costs & 2163 & 1791 & 1582 & 2687 & 2303 & 2034 & 1835 \\
\hline Profitability & -362 & 14 & 231 & -873 & -490 & -221 & -22 \\
\hline
\end{tabular}

In Figure 1 the profitability per holding and year is presented for the different flock sizes in the basic case as well as in the sensitivity analyses with $50 \%$ lower costs of new buildings and 1000 SEK per ha and year opportunity cost of arable land. The figure suggests that halved building costs and at least 500 ewes are required for break-even in the case of new resources provided at market prices. Still larger flocks can be profitable if the building costs can be reduced by erecting simple but well functioning constructions or by the possibility of receiving investment subsidies. 
Figure 1. Calculated profitability of different flock sizes in Swedish lamb production with slaughter in late winter, spring and early summer. SEK per flock in 2006 prices.

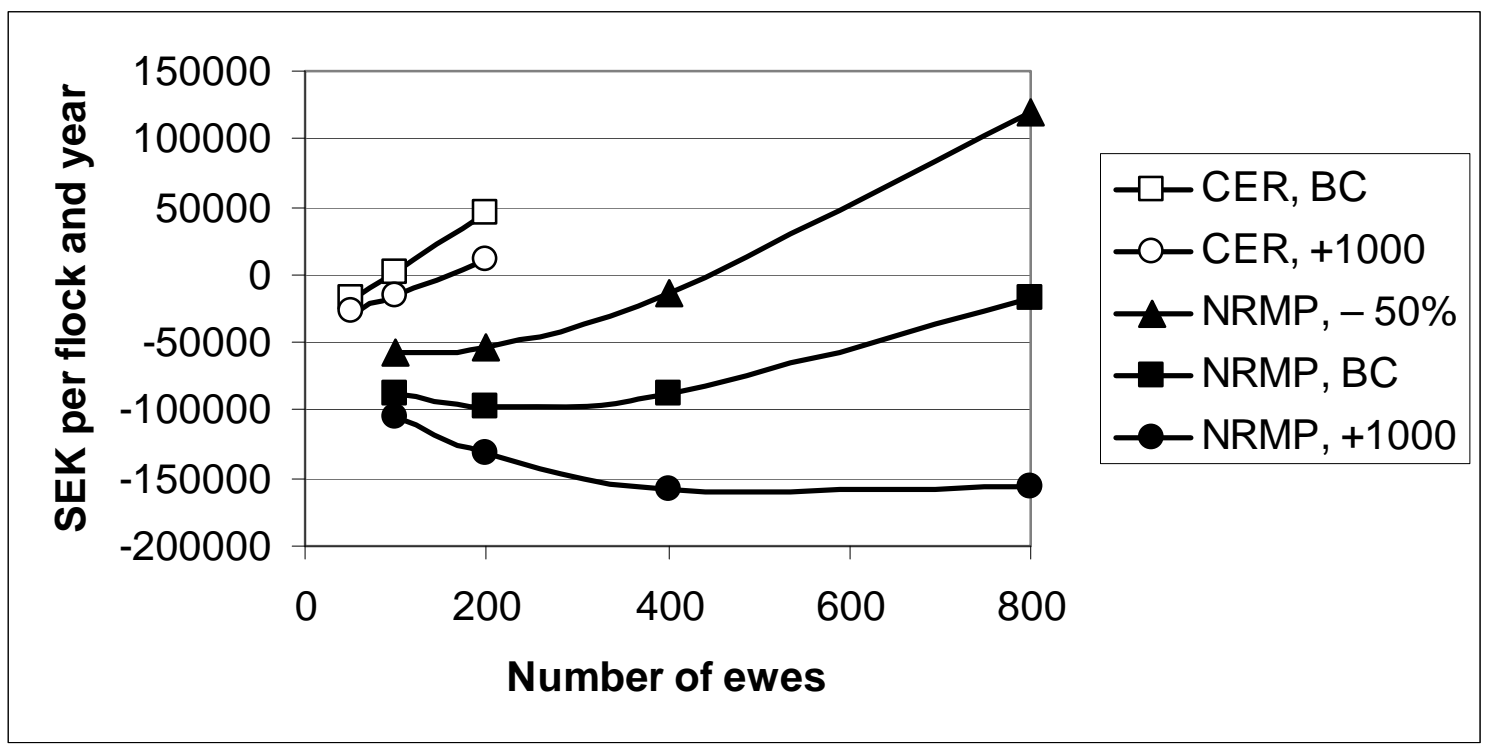

CER $=$ Cheap Existing Resources; NRMP = New Resources provided at Market Prices;

$\mathrm{BC}=$ Basic Calculation; $+1,000=$ sensitivity analysis with $1,000 \mathrm{SEK}$ ha $^{-1}$ opportunity cost of land; -50 $\%=$ sensitivity analysis with $50 \%$ lower costs of new buildings.

The 1,000 SEK per ha opportunity cost reduces the economic results especially in large flocks requiring large areas. The cost of permanent semi-natural grassland, not suitable for grain production, is supposed to remain zero. Thus, economic result from lamb production based exclusively on arable land suitable for grain production can be affected still further than suggested by the figure by high grain prices increasing the opportunity cost of arable land. Small flocks using cheap existing resources are not so badly affected indicating that they are less risky than investing in large scale lamb production.

In forest dominated regions with small and scattered fields and low grain yields the opportunity cost of land is zero even at present high grain prices (Sveriges lantbruksuniversitet, 2008). However, a severe obstacle for profitable lamb production in forest dominated regions is the lack of large enough areas for producing pasture and silage for larger sheep flocks. A flock of 500 ewes with lamb slaughtered in late winter, spring and early summer requires 70-120 ha of pasture and arable land for winter feed production depending on the intensity (Kumm, 2006). This is 2-4 times larger than the average size of agricultural land on farm holdings in forest dominated regions (Jordbruksverket, 2007). Production with all lambs slaughtered in winter requires a somewhat smaller area due to a larger part of the feed being purchased concentrates, but production with autumn slaughter requires an even larger area due to nearly $100 \%$ home grown feed (Kumm, 2006).

\subsection{Interviews}

According to the interviews, lack of accessible cheap additional pastures and fields for silage production in the neighborhood is the most severe lasting obstacle for further expansion of the flock size (Table 3 ). If additional land for a growing lamb production 
enterprise is to be found still further away from the farm centre there will be increasing marginal costs for transportation of feed and grazing animals as well as for daily supervision of grazing sheep. In order to provide a large flock with feed, despite lack of cheap accessible land in the neighborhood, the following solutions have been carried out by the interviewees: leasing cheap land further away and transporting feed and grazing animals, increasing feed production per hectare by (increased) input of commercial fertilizers, transforming forest land to pasture after the final cutting, and trading forest land for agricultural land with neighbors.

Table 3. Growth sacrifices and obstacles experienced by 20 lamb producers who have built up for Swedish conditions large sheep flocks.

\begin{tabular}{|l|c|}
\hline & $\begin{array}{l}\% \text { of interviewees } \\
\text { experienced problems }\end{array}$ \\
\hline Temporary growth sacrifices & 20 \\
\hline Transmission of infections by bought ewes & 60 \\
\hline Low production due to high replacement or primiparous \% & 25 \\
\hline Low yield and/or reclamation costs of additional land & 50 \\
\hline Lasting growth obstacles & 35 \\
\hline Lack of cheap accessible additional land & \\
\hline Heavy burden of work especially during lambing & \\
\hline
\end{tabular}

New buildings that are partially unused until the flock has been expanded to the intended number of sheep imply reduced revenue but full capital costs of buildings and, thus, lower profitability more than shown in Figure 1. This growth sacrifice can be reduced by large-scale once only purchase of ewes and/or a high level of replacement with own ewe lambs. However, buying in live animals increases risks of transmitting infections from other flocks, high replacement percentage of ewe lambs implies a low selection pressure and large proportion of primiparous ewes results in low production for the first 1-2 years. Most of the interviewees $(80 \%)$ have experienced these kinds of growth sacrifices. Another growth sacrifice experienced by some interviewees, in forest dominated regions with declining agriculture operations, was the cost of reclamation of abandoned and overgrown fields with low yields the first years after tenancy. Many interviewees pointed out negative cash-flow problems after investments in sheep, buildings and machinery before they achieved full revenues. This was the case even where the above mentioned growth sacrifices had been limited and the long run was profitability acceptable.

The interviews suggest that a good strategy to reduce these growth sacrifices and chashflow problems is to build up as large as possible a flock within the existing buildings and only then build a new sheep shed. Then, the new building is filled up as soon as possible by the farmer's own replacements and/or purchase of ewes from one or a few guaranteed infection-free flocks. During the beginning of this growth process the prospective professional lamb producers can earn their living from other production on the farm or a non-farming job, running the sheep husbandry part time. During this period they can also search for cheap additional land within reasonable distance and accomplish possible necessary reclamation work on new fields needed for the future fully expanded flock. During this gradual growth process the new lamb producer also gains knowledge that is 
important especially as most farmers in Sweden lack experience of larger scale lamb production.

Most interviewees had reduced growth sacrifices and long run profitability problems connected with machinery investments to a large extent by buying soil cultivation and silage harvesting work from agricultural contractors. Only a few large holdings and one sheep farm situated far away from contractors had a complete set of their own mechanical equipment.

The heavy burden of work during lambing is a severe obstacle for further expansion according to the interviewees. The work burden during lambing is especially severe in flocks with high fertility ewes having three or more lambs in many cases. Some interviewees have found that changing from winter-lambing indoors to summer-lambing outdoors had reduced this burden. However, summer lambing and slaughter during late winter, spring and early summer assumes that the lambs are relatively old at slaughter, which results in larger feed consumption than supposed in the presented calculations.

\section{Discussion}

4.1. Mostly small flocks despite economies of scale

By enlarging sheep flocks from 100 to 800 ewes the costs of buildings and labor can be reduced by nearly 800 SEK per ewe in the case of new resources and market prices. This is more than total feed costs indicating that economies of scale are essential for economically sustainable lamb production (Table 2). However, most Swedish sheep flocks are very small despite economies of scale (Table 1). It seems to be more attractive to have a well paid nonfarming job in combination with a small part time or hobby sheep flock for keeping the landscape open around the residence, than managing a large full time sheep enterprise. Figure 1 also indicates that the profitability deteriorates if a flock with 100 ewes, managed by cheap existing resources including part time work with relatively low demand of remuneration, is extended to 400 ewes demanding new resources provided at market price including new buildings, new fences and full time work requiring 170 SEK per hour. By further extending the flock to at least 500 ewes the production can become profitable if the cost of new buildings can be reduced by $50 \%$ to circa 200 SEK per ewe and year.

A smaller part time flock in combination with well paid non-farming jobs for husband and wife will generally give higher family income and is probably less strenuous and risky than lamb production as the only mean of the family's livelihood. The interviews with, for Swedish conditions, large lamb producers also suggest that satisfying the family's total set of economic and non-economic goals is more important than maximizing the profitability of the lamb production. This is in accordance with the general observation by Simon (1983 \& 1997) that owners of business enterprises satisfy a set of goals rather than maximize the profit. The satisfier changes his production, e.g. increase the sheep flock, only if and then it is needed for satisfying the goals. Not only in Sweden but generally in Northern Europe (Dýrmundsson, 2006) there will probably be a development to larger flocks where conditions are favorable, and a trend towards part time flocks using cheap existing resources in other cases. But cheap existing resources do not last for ever so 
building up large flocks deriving advantage from economies of scale is important for an economically sustainable lamb production.

\subsection{Growth creating resources}

Most of the interviewed large lamb producers plan to, or consider, further increasing their sheep flocks in order to better satisfy their goals. An important reason is partly unused indivisible resources that have arisen during the earlier growth. For example, own working time after leaving a non-farming job for full time sheep husbandry or a procured complete ration feeder which is profitable even in the present flock, but has capacity for a much larger flock. In the process of operation and expansion an ability to manage still larger flocks of sheep is also being developed. Such resources, including e.g. labor, machines and ability, can at zero or low marginal costs be used for further extended production by combining them with other resources. Because of such resources created during the growth process there is no optimal firm size as supposed in neo-classical economic theory according to Penrose's (1980) general theory. She does not see any economically motivated end of the growth process but growth sacrifices stemming mainly from difficulties for management in planning and organizing the growth process. Such growth sacrifices in Swedish lamb production are, according to the interviews, problems of getting hold of good breeding stock and cheap additional land, organizing transport of feed and animals between the farm centre and land further away, supervising lambing ewes and grazing animals on remote pastures, and managing the financial cashflow.

Experienced farmers with very large flocks selling many lambs and purchasing much input can probably obtain higher price of lamb thanks to quantity bonuses from the abattoirs as well as higher discount on e.g. concentrate than the regular bonuses and discounts supposed in the calculations. This can result in larger economies of scale than indicated in Table 2 and Figure 1.

\subsection{Economies of scale by large pasture-forest mosaics}

Lack of cheap accessible land for feed production is the main obstacle for increasing the lamb production according to the interviews. In fertile flatland districts high opportunity costs of arable land is the main obstacle especially if the present (2007/08) high grain prices continue. In forest regions with small scattered and fields with high cultivating costs and low grain yields the opportunity cost is zero even at present high grain prices (Sveriges lantbruksuniversitet, 2008). Statistics and forecasts indicate that the area of land without opportunity cost is increasing. Since the decoupling of the EU-income support for grain production in 2005 the area of grain has decreased by 60,000 ha $(=25 \%)$ in the forest dominated regions of Sweden at the same time as the number of livestock units based on grass (cattle + sheep) has also decreased (Jordbruksverket \& Statistiska centralbyrån, 2004 \& 2007; Statistiska centralbyrån, 2007). Up to the year 2020 the area of semi-natural pasture not in use is forecast to increase by 100,000-400,000 ha, principally situated in forest regions (Jordbruksverket, 2007).

Low or zero opportunity cost of land suggests that the conditions for profitable lamb production is best in forest dominated regions. However, small and scattered pastures resulting in high fencing costs per ha and high labor demand for the daily supervision of the sheep and for moving them between different paddocks are severe problems in most 
forest dominated districts. This problem can be at least partly solved by enlarging the present pastures by incorporating adjacent overgrown pastures, marginal arable land and forest land. By restoring the overgrown pastures, re-seeding arable land with pasture grass, grazing some parts of the forest, and transforming other parts of it to pasture after clear-cutting, there will be enough pasture for larger flocks (Kumm, 2007). In a large connected pasture it might also be easier to manage the increasing predator problems than in several small pastures surrounded by forest. The incremental cost of predator fence is lower per hectare in a large rectangular paddock than in small paddocks with irregular sizes.

Experiences from a time when forest grazing was common in Sweden (Björkbom \& Schager, 1916; Geete \& Grinndal, 1923) suggests that well managed sheep grazing of forest in large connected paddocks, which also include cultivated pasture, will have more advantages than disadvantages for timber production including weed control during the reforestation stage, provided that the grazing pressure is not too high. Both Norwegian experiments (Bjor \& Graffer, 1962) and present practical experience (Kumm, 2007) also show that the lamb growth can be as good on forest grazing as on grazing in open pastures provided that the forest area grazed per head is large enough. If the pasture area can become extended by using presently overgrown pastures and forest land, less grazing on fields suitable for winter feed production will be needed and, thus, more area will become available for winter feed production.

Large pasture-forest mosaics not only have economic but in many cases also cultural historic and bio-diversity advantages. They will be more like the Swedish 19th century landscape than the present landscape dominated by dense spruce forests and rectangular intensively cropped arable fields (Ihse, 1995; Lindborg, 2006). Large connected pasture mosaics also reduce the risk of local extinction of grassland species thanks to larger population sizes and better possibilities of re-colonization (Kiviniemi, 1997; Eriksson et.al., 2002; Cousins \& Lindborg, 2008). Thus, they should be well qualified for environmental payment, which is critical for profitable Swedish lamb production according to Table 1 .

Lamb production compared with beef production

The problem of getting hold of enough land for attaining economies of scale, including full cost coverage in the case of new resources provided at market prices, is more severe in cow-calf production than in lamb production. In lamb production around 100 ha might be enough for full cost coverage whereas a much larger area is needed for breeding cows for beef production (Kumm, 2006). Also the time, and thus growth sacrifices, connected with building up large operations are longer for suckle cows than for ewes due to lower fertility ( 1 calf versus $\geq 2$ lambs per year) and higher age at first delivery ( 2 years versus 1 year). 


\section{Conclusions}

Sheep flocks of more than 500 ewes can be profitable under Swedish conditions whereas smaller flocks are unprofitable unless they are managed by cheap existing resources. Pastures for profitable production can be created by enlarging present pastures in forest dominated regions by incorporating adjacent overgrown pastures, marginal arable land and forest land. Profitable lamb production also requires lower costs of new sheep sheds than what is now common in Sweden.

\section{Acknowledgements}

This study was financed by the Swedish Farmers' Foundation for Agricultural Research.

\section{References}

Bjor, K., Graffer, H., 1962. Beiteundersøkelser på skogsmark (Investigation on Grazing in Woodland), Norges landbruksvitenskaplige forskningsråd, Mariendals boktryckeri, Gjøvik, 365 pp.

Björkbom, C., Schager, N., 1916. Om skogsbetet (About Forest Grazing).

Skogsvårdsföreningens folkskrifter, Svenska Skogsvårdsföreningen, Stockholm, 64 pp.

Cousins, S.A.O., Lindborg, R., 2008. Remnant grassland habitats as source communities for plant diversification in agricultural landscapes. Biol. Conserv. (141) 233-240.

Djurskyddsmyndigheten, 2004. Djurskyddsmyndighetens föreskrifter och allmänna råd om djurhållning inom lantbruket m.m (Regulations and general advices by the Swedish Animal Welfare Agency for animal husbandry in agriculture), DFS 2004:17, Saknr L 100, Skara, 51 pp.

Dýrmundsson, Ó. R., 2006. Sustainability of sheep and goat production in Northern European countries - From the Artic to the Alps. Small Rumin. Res. (62) 151-157.

Eriksson, O., Cousins, S. A. O., Bruun, H. H., 2002. Land-use history and fragmentation of traditionally managed grasslands in Scandinavia. J. Veg. Sci. (13) 743-748.

Eurostat, 2008. Structure of agricultural holdings.

Geete, E., Grinndal, T., 1923. Anvisningar i skogsbruk (Instructions in forestry), Svenska skogsvårdsföreningens förlag, Stockholm, 85 pp.

Ihse, M., 1995. Swedish agricultural landscapes - patterns and changes during the last 50 years, studied by aerial photos. Landsc. Urban Plann. (31) 21-37.

Jordbruksverket, 2005. Svenskt jordbruk i siffror 1800-2004 (Swedish Agriculture in figures 1800-2004), Statistik från Jordbruksverket, Statistikrapport 2005:6, Jönköping, 39 pp.

Jordbruksverket, 2006. Marknadsöversikt - animalier, (Market survey - animal products), Rapport 2006:35, Jönköping, 244 pp. 
Jordbruksverket, 2007. Jordbrukets miljöeffekter 2020 - en framtidsstudie (Environmental effects of the agriculture - a future study), Rapport 2007:7, Jönköping, $93 \mathrm{pp}$.

Jordbruksverket och Statistiska Centralbyrån, 2004 \& 2007. Jordbruksstatistisk årsbok (Yearbooks of agricultural statistics).

Kiviniemi, K., 1997. A study of seed dispersal and recruitment of plants in a fragmented habitat, Växtekologi, Botaniska Institutionen, Stockholms universitet 1997:3.

Kumm, K.-I., 2006. Vägar till lönsam nöt- och lammköttsproduktion (Scenarios for profitable beef and lamb production), Rapport 11, institutionen för husdjurens miljö och hälsa, SLU, Skara, 99 pp.

Kumm, K.-I., 2007. Lönsam betesdrift genom stora sammanhängande betesmarker (Profitable grazing by large connected pastures), Rapport 16 institutionen för husdjurens miljö och hälsa, SLU, Skara, 42 pp.

Lindborg, R., 2006. Naturbetesmarker i ett landskapsperspektiv (Semi-natural pastures in a landscape perspective), CBM:s skriftserie 12, Uppsala, 56 pp.

Meat \& Wool New Zealand, 2008. Sheep and Beef Farm Surveys. http://www.meatnz.co.nz/main.cfm?id=1.

Penrose, E. T., 1980. The theory of the growth of the firm, Second Edition, Blackwell, Oxford, $272 \mathrm{pp}$.

Simon, H. A., 1983. Reason in human affairs. Stanford University Press, 128 pp.

Simon, H. A., 1997. Administrative behavior, Fourth Edition, Macmillan, New York, 384.

Sjödin, E., 2007. Får (Sheep), Bokförlaget Natur och Kultur, Stockholm, 248 pp.

Spörndly, R., 2003. Fodertabeller för idisslare (Feed tables for ruminants), Rapport 257 från Institutionen för husdjurens miljö och hälsa, SLU. Uppsala, 96 pp.

Statistiska Centralbyrån, 2007. Jordbruksmarkens användning 2007 (Use of agricultural land in 2007), JO 10 SM 0702.

Statistiska centralbyrån, 2008. Sammanställning av data i lantbruksregistret (Compilation of data from the Farm Register).

Sveriges lantbruksuniversitet, 2006 \& 2008. Områdeskalkyler för jordbruk (Regional budgets for agricultural production), Uppsala. 